\title{
DNA Damage, Cell Cycle Arrest, and Apoptosis Induction Caused by Lead in Human Leukemia Cells
}

\author{
Clement G. Yedjou *, Hervey M. Tchounwou and Paul B. Tchounwou \\ Received: 16 August 2015; Accepted: 19 October 2015; Published: 22 December 2015 \\ Academic Editor: Howard W. Mielke \\ Natural Chemotherapeutics Research Laboratory, NIH-Center for Environmental Health, College of Science, \\ Engineering and Technology, Jackson State University, 1400 Lynch Street, P.O. Box 18540, Jackson, MS 39217, \\ USA; hervey.tchounwou@students.jsums.edu (H.M.T.); paul.b.tchounwou@jsums.edu (P.B.T.) \\ * Correspondences: clement.yedjou@jsums.edu; Tel.: +1-601-979-0215; Fax: +1-601-979-5853
}

\begin{abstract}
In recent years, the industrial use of lead has been significantly reduced from paints and ceramic products, caulking, and pipe solder. Despite this progress, lead exposure continues to be a significant public health concern. The main goal of this research was to determine the in vitro mechanisms of lead nitrate $\left[\mathrm{Pb}\left(\mathrm{NO}_{3}\right)_{2}\right]$ to induce DNA damage, apoptosis, and cell cycle arrest in human leukemia (HL-60) cells. To reach our goal, HL-60 cells were treated with different concentrations of $\mathrm{Pb}\left(\mathrm{NO}_{3}\right)_{2}$ for $24 \mathrm{~h}$. Live cells and necrotic death cells were measured by the propidium idiode (PI) assay using the cellometer vision. Cell apoptosis was measured by the flow cytometry and DNA laddering. Cell cycle analysis was evaluated by the flow cytometry. The result of the PI demonstrated a significant $(p<0.05)$ increase of necrotic cell death in $\mathrm{Pb}\left(\mathrm{NO}_{3}\right)_{2}$-treated cells, indicative of membrane rupture by $\mathrm{Pb}\left(\mathrm{NO}_{3}\right)_{2}$ compared to the control. Data generated from the comet assay indicated a concentration-dependent increase in DNA damage, showing a significant increase $(p<0.05)$ in comet tail-length and percentages of DNA cleavage. Data generated from the flow cytometry assessment indicated that $\mathrm{Pb}\left(\mathrm{NO}_{3}\right)_{2}$ exposure significantly $(p<0.05)$ increased the proportion of caspase-3 positive cells (apoptotic cells) compared to the control. The flow cytometry assessment also indicated $\mathrm{Pb}\left(\mathrm{NO}_{3}\right)_{2}$ exposure caused cell cycle arrest at the $\mathrm{G}_{0} / \mathrm{G}_{1}$ checkpoint. The result of DNA laddering assay showed presence of DNA smear in the agarose gel with little presence of DNA fragments in the treated cells compared to the control. In summary, $\mathrm{Pb}\left(\mathrm{NO}_{3}\right)_{2}$ inhibits HL-60 cells proliferation by not only inducing DNA damage and cell cycle arrest at the $\mathrm{G}_{0} / \mathrm{G}_{1}$ checkpoint but also triggering the apoptosis through caspase-3 activation and nucleosomal DNA fragmentation accompanied by secondary necrosis. We believe that our study provides a new insight into the mechanisms of $\mathrm{Pb}\left(\mathrm{NO}_{3}\right)_{2}$ exposure and its associated adverse health effects.
\end{abstract}

Keywords: lead nitrate; HL-60 cells; DNA damage; apoptosis; cell cycle; cellometer vision

\section{Introduction}

Lead is a malleable substance found naturally in the Earth's crust, and also extracted from other metals, such as ore, copper, and silver. Throughout history, lead has been used in various industrial applications including the manufacturing of fossil fuels, paint, plumbing materials, batteries, and cosmetics [1]. Despite its beneficial industrial uses, lead has caused environmental contamination of the air, water, and soil [1]. Environmental contamination of lead is often toxic to both human and animal health. Recent studies conducted by US Environmental Protection Agency reported that children and pregnant women are the population most vulnerable to the toxic effects of lead exposure [1]. A widely cited scientific paper suggests that lead exposure during pregnancy can inversely affect fetal growth, neurological development, and cause spontaneous abortion [2]. Worldwide, lead is considered as a serious occupational hazard [3]. Previous study in 
our laboratory showed that treatment of human leukemia (HL-60) cells with lead nitrate significantly increased lipid hydroperoxide levels, a major degradation product of unsaturated phospholipids and glycolipids [4]. Consistent with our previous finding, lead is reported to cause oxidative stress by generating the release of reactive oxygen species (ROS), such as superoxide radicals, hydrogen peroxide and hydroxyl radicals and lipid peroxides $[5,6]$. It has been shown that exposure to lead enhances intracellular ROS production, lipid peroxidation, and tissue damage in animal reproductive systems [7]. It has also been reported that lead exposure alters the activities of antioxidant enzymes, such as glutathione peroxidase, catalase and superoxide dismutase in various experimental animals $[8,9]$. Bressler and collaborators reported that lead exposure causes neurotoxic effects, such as behavioral abnormalities, learning impairment, decreased hearing, and impaired cognitive functions in human and experimental animals [10]. Maternal lead exposure has been linked to a large number of adverse health effects of developing fetus [2] and associated with increases in maternal blood pressure in pregnant women [11].

Although much more research is needed to determine the minimum levels of exposure that cause negative health consequences, scientific data have provided enough information to conclude that lead poses a health risk to both pregnant women and their babies [12]. Scientific data also highlight oxidative stress as a key factor in lead-associated kidney damage, but it has been unclear how the stress is generated [13]. Lead affects numerous organ systems in the body, but its specific mechanisms of damage are not always known. Thus far, many scientific reports on lead have been focused on its immunotoxic effects in animal experiments and people with occupational exposure to lead [14,15]. Presently, there are limited reports on the influence of lead exposure on lymphocytes. Therefore, the present study was designed to evaluate the in vitro mechanisms of lead induces toxicity, DNA damage, cell cycle arrest, and apoptosis of human leukemia (HL-60) cells.

\section{Materials and Methods}

\subsection{Chemicals and Media}

We obtained reference solution $(1000 \pm 10 \mathrm{ppm})$ of lead nitrate [ $\left.\mathrm{Pb}\left(\mathrm{NO}_{3}\right)_{2}\right]$ (CAS No. 10099-74-8, Lot No. 981735-24) with a purity of $100 \%$ from Fisher Scientific in Fair Lawn, New Jersey. Growth medium RMPI 1640 containing $1 \mathrm{mmol} / \mathrm{L}$ L-glutamine was purchased from Gibco BRL products (Grand Island, NY, USA). Fetal bovine serum (FBS), phosphate buffered saline (PBS), and propidium assay were obtained from Sigma Chemical Company (St. Louis, MO, USA). Active caspase-3 kit was obtained from BD Biosciences (Pharmingen, CA, USA).

\subsection{Cell/Tissue Culture}

The HL-60 cell line was originally derived from a 36 year-old Caucasian female with acute promyelocytic leukemia (APL). In the laboratory, HL-60 cells were maintained as previously described [16]. Briefly, cells were grown in RMPI 1640 medium containing $1 \mathrm{mmol} / \mathrm{L}$ L-glutamine (GIBCO/BRL, Gaithersburg, MD, USA) and supplemented with $10 \%(v / v)$ fetal bovine serum (FBS), and $1 \%(\mathrm{w} / \mathrm{v})$ penicillin/streptomycin. Cells were observed under the inverted microscope daily following by incubation in a humidified $5 \% \mathrm{CO}_{2}$ incubator at $37^{\circ} \mathrm{C}$. Three times a week, cells were manually counted using a hemocytometer and diluted to maintain a density of $5 \times 10^{5}$ cells $/ \mathrm{mL}$.

\subsection{Biochemical Test for Live Cells and Necrotic Death Cells by Cellometer Imaging}

To determine the cytotoxic effect of $\mathrm{Pb}\left(\mathrm{NO}_{3}\right)_{2}$ in vitro, we measured cell viability by propidium iodine (PI) staining using the Cellometer Imaging system. Briefly, $1 \times 10^{6}$ cells $/ \mathrm{mL}$ per treatment in 3 replicates was harvested, washed, and re-suspended in $1 \mathrm{~mL}$ of culture media. Five microliters of propidium iodide (PI) was added to $100 \mu \mathrm{L}$ of cell suspension taken out from each sample. Samples were gently mixed and incubated for $20 \mathrm{~min}$ at room temperature in dark. Samples were mixed again and $20 \mu \mathrm{L}$ of each sample was loaded into the cellometer counting chamber. Samples in the cellometer 
counting chamber were analyzed by the Cellometer Vision. Both cell concentration and viability were determined with the Vision software. Hence, the Cellometer Vision-based imaging was successfully used in our laboratory to identify live and necrotic death cells [17].

\subsection{Biochemical Test for DNA Damage by Comet Assay}

The comet assay was carried out by the method previously described by Collins and his collaborators [18,19] with some modifications [20]. Briefly, $1 \times 10^{5}$ cells were seeded and allowed to attach for at least $24 \mathrm{~h}$ before treatment with lead nitrate. At the end of treatment, cells were centrifuged, washed with PBS free calcium and magnesium, and re-suspended in $100 \mu \mathrm{L}$ PBS. Five hundred microliters of melted LMAgarose plus $50 \mu \mathrm{L}$ of the cells suspension were mixed and $75 \mu \mathrm{L}$ was pipetted onto a pre-warmed cometslide. The cometslides were placed flat in the dark at $4{ }^{\circ} \mathrm{C}$ for $10 \mathrm{~min}$ and then immersed in prechilled lysis solution at $4{ }^{\circ} \mathrm{C}$ for $40 \mathrm{~min}$. After the lysis, the slides were immersed in Alkaline Solution for $40 \mathrm{~min}$ at room temperature in the dark. Next, the samples were electrophoresed at low voltage $\left(300 \mathrm{~mA}, 25 \mathrm{~V}, 4{ }^{\circ} \mathrm{C}\right)$ for $20 \mathrm{~min}$ and stained with SYBR Green designed for $6 \mathrm{~h}$. Samples were viewed with an Olympus fluorescence microscope and analyzed using LAI's Comet assay Analysis System software (Loates Associates, Inc. Westminster, MD, USA).

\subsection{Biochemical Test for Cell Cycle Distribution by Flow Cytometry}

For this experiment, cells were cultured in 6 well plates. Control (untreated) and treated cells with $\mathrm{Pb}\left(\mathrm{NO}_{3}\right)_{2}$ were harvested from 6 well plates after $24 \mathrm{~h}$ of exposure. Harvested cells were washed twice with phosphate-buffered saline (PBS) and $5 \times 10^{6}$ cells $/ \mathrm{mL}$ per sample were fixed with $70 \%$ methanol on ice for $10 \mathrm{~min}$. After cells fixation, cell pellet was then suspended in $0.5 \mathrm{~mL}$ PBS containing propidium iodide $(50 \mu \mathrm{g} / \mathrm{mL})$ and DNase-free RNase $(100 \mu \mathrm{g} / \mathrm{mL})$ for $15 \mathrm{~min}$. The relative number of cells in the different phases was assessed by flow cytometry (FACS Calibar; Becton-Dickinson) using CellQuest software, and the percentages of cells calculated in G0/G1, S and G2/M phases of the cell cycle.

\subsection{Biochemical Test for Apoptosis by DNA Laddering Assay}

We recently demonstrated lead nitrate induced apoptosis in human leukemia (HL-60) cells through induction of phosphatidylserine externalization and caspase-3 activation [16]. To further confirm that lead nitrate is a potential apoptotic agent, we performed DNA Laddering Assay. Briefly, $2 \mathrm{~mL}$ of cells $\left(1 \times 10^{6}\right.$ cells $\left./ \mathrm{mL}\right)$ untreated or treated with 10,20 and $30 \mu \mathrm{g} / \mathrm{mL}$ of lead nitrate were incubated for $24 \mathrm{~h}$. After the incubation period, cellular DNA was extracted using genomic DNA isolation reagents from Roche Molecular Biochemicals (Indianapolis, IN) according to the manufacturer's protocol. After extraction, samples were placed into the well of agarose gel (1.2\%, $\mathrm{w} / \mathrm{v}$ ) and electrophoresed at 75 volt until the purple tracer marker migrated to approximately $2 \mathrm{~cm}$ before the end of the gel. After electrophoresis, the gel was stained with ethidium bromide, and photographed under UV light as previously described [21].

\subsection{Statistical Analysis}

Data were presented as means \pm SDs. Statistical analysis was done using one way analysis of variance (ANOVA Dunnett's test) for multiple samples. Student's paired test was used to analyze the difference between the controls and lead nitrate-treated cells. All $p$-values $<0.05$ were considered to be significant. Graphs were made to illustrate the concentration-response relationship with respect to cell death, DNA damage, and apoptosis. 


\section{Results and Discussion}

\subsection{Lead Nitrate Inhibited Cell Growth}

Cell viability of human leukemia (HL-60) cells in the absence and presence of lead was tested after $24 \mathrm{~h}$ exposure by propidium iodide assay based on cell density computed by the brightfield images using the cellometer vision. Figure 1 shows the results obtained after treatment of the HL-60 cells with three concentrations of lead nitrate including 10, 20 and $30 \mu \mathrm{g} / \mathrm{mL}$ lasting $24 \mathrm{~h}$. A clear positive concentration-dependent relationship was observed in the percentage of cell death and increasing concentrations of lead nitrate (Figure 1). These results are agreement with those of previous investigations reporting a marked reduction in the viability of cancer cells following exposure to lead $[22,23]$. Recent study demonstrated that lead affects essentially every organ system in the body, including the hematopoietic, cardiovascular, renal and skeletal systems with the central nervous system being more sensitive to the effects of lead exposure [24]. The current reference lead concentration in blood set by Centre for Disease Control for identification and monitoring of children who are exposed to high level of lead is $\geqslant 5 \mu \mathrm{g} / \mathrm{dL}$ [25]. The blood lead level rises within hours of exposure and remains elevated for several weeks thereafter [26]. Due to lead's short half-life time in the blood, blood lead tests cannot be used to diagnose or rule out evidence of exposure that occurred more than six weeks before testing. Studies show that even low-level exposures to lead impair cell-mediated immunity by upsetting the balance between Th1- and Th2- like Tlymphocytes, which alters cytokine expression $[27,28]$.

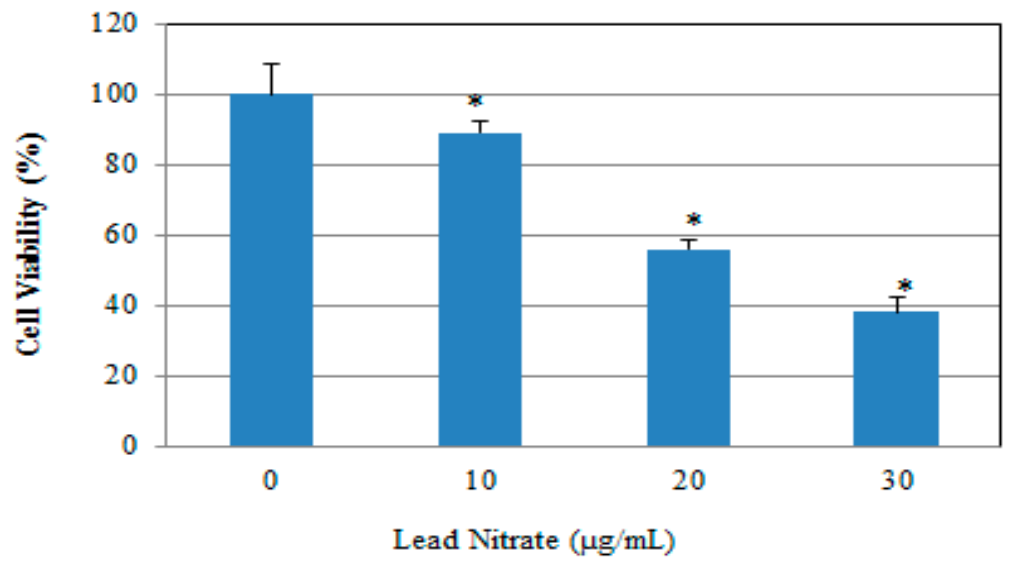

Figure 1. Cytotoxic effect of $\mathrm{Pb}\left(\mathrm{NO}_{3}\right)_{2}$ to HL-60 cells. HL-60 cells were cultured in the absence or presence of $\mathrm{Pb}\left(\mathrm{NO}_{3}\right)_{2}$ for $24 \mathrm{~h}$. Cell viability was determined based on the propidium iodide assay. Each point represents a mean value of 3 experiments with 6 replicates per concentration. $p<0.05$ versus compared with control group. * Significantly different $(p<0.05)$ from the control, according to the Dunnett's test.

\subsection{Lead Nitrate Induced Necrotic Cell Death}

We analyzed necrotic cell death in the absence and presence of $\mathrm{Pb}\left(\mathrm{NO}_{3}\right)_{2}$ after $24 \mathrm{~h}$ exposure by propidium iodide (PI) assay based on necrotic cells population computed by the fluorescent images using the Cellometer Vision. We found that lead nitrate induced necrotic cell death in a concentration-dependent manner (Figure 2). The number of cells stained with PI increased significantly in lead nitrate-treated cells compared with the control group. These results led us to conclude that lead nitrate induces necrosis in human leukemia (HL-60) cells. To the best of knowledge, we reported for the first time that lead nitrate is able to cause cell death through the necrosis pathway. As shown on Figure 2, brightfied images showed a gradual decrease in the cell viability of leukemic cells compared to the control while fluorescent images showed 
a gradual increase in the proportion of necrotic cell death with increasing concentrations of lead nitrate compared to the control. The fluorescent images showed strong morphological changes in lead-treated cells compared to the control group. Necrosis is a cell death process that is morphologically characterized by a gain in cell volume, swelling of organelles, plasma membrane rupture and subsequent loss of intracellular contents. This is in contrast to programmed cell death (apoptosis), although it was long thought that necrosis is an uncontrolled cell death that is characterized by progressive loss of cytoplasmic membrane integrity, rapid influx of $\mathrm{Na}^{+}, \mathrm{Ca}^{2+}$, and water, resulting in cytoplasmic swelling and nuclear pyknosis [29].

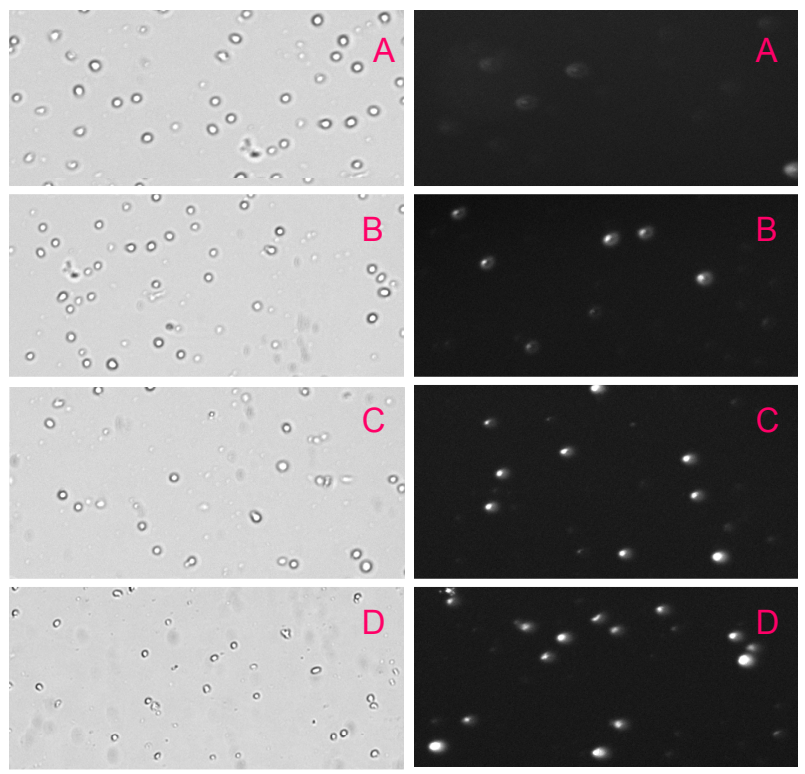

Figure 2. Bright field images (left) and fluorescent images (right) of HL-60 cells exposed to $\mathrm{Pb}\left(\mathrm{NO}_{3}\right)_{2}$ for $24 \mathrm{~h}$. HL-60 cells were exposed to different concentrations of $\mathrm{Pb}\left(\mathrm{NO}_{3}\right)_{2}$. (A) - control; (B) $-10 \mu \mathrm{g} / \mathrm{mL} \mathrm{Pb}\left(\mathrm{NO}_{3}\right)_{2}$; (C) $-20 \mu \mathrm{g} / \mathrm{mL} \mathrm{Pb}\left(\mathrm{NO}_{3}\right)_{2}$; and (D) $-30 \mu \mathrm{g} / \mathrm{mL} \mathrm{Pb}\left(\mathrm{NO}_{3}\right)_{2}$. Images were taken using the Cellometer Vision (at $10 \times$ magnification).

\subsection{Lead Nitrate Induced Genotoxic Damage}

The Comet assay is a highly sensitive technique to study DNA damage caused by metals [21,30]. In the present work, we used this technique to study lead nitrate-induced DNA damage in exposed HL-60 cells. Representative Comet assay images of control and lead nitrate-treated cells stained with SYBR Green are presented in Figure 3. As denoted in this figure, there is gradual increase in the mean values of comet tail length, tail moment, and percentages of DNA cleavage in HL-60 cells, with increasing concentrations of lead nitrate. The percentages of DNA cleavage and tail length are represented in Figure 4. Overall, the results generated from the comet assay indicated that lead nitrate is highly genotoxic to leukemia cells. Although it is generally accepted that lead is a possible genotoxic carcinogen in humans, it remains unclear how lead nitrate causes genetic damage in humans. Our Comet assay results indicate that lead nitrate exposure is able to induce DNA damage in human leukemia cells in concentration-dependent manner. This finding is in agreement with previous reports showing that lead causes destabilization of DNA, compaction and aggregation of chromatin, and impaired DNA and RNA synthesis [31] and Kupffer cell-mediated cell death in the liver [32]. Other reports indicated that lead causes point mutations in Chinese hamster ovary cells [33], abnormal base pairing [34], formation of micronuclei, chromosome aberration, and sister chromatid exchanges [35]. Studies by Roy and his group showed that lead acetate induced mutagenicity at a toxic dose at the E. coli gpt locus transfected to V79 cells [36]. They also reported that toxic doses of lead acetate and lead nitrate induced DNA breaks at the E. coli gpt locus transfected 
to V79 cells [36]. Another study by Wise and his collaborators found no evidence for direct genotoxic or DNA-damaging effects of lead except for lead chromate. They pointed out that the genotoxicity may be due to hexavalent chromate rather than lead [37].
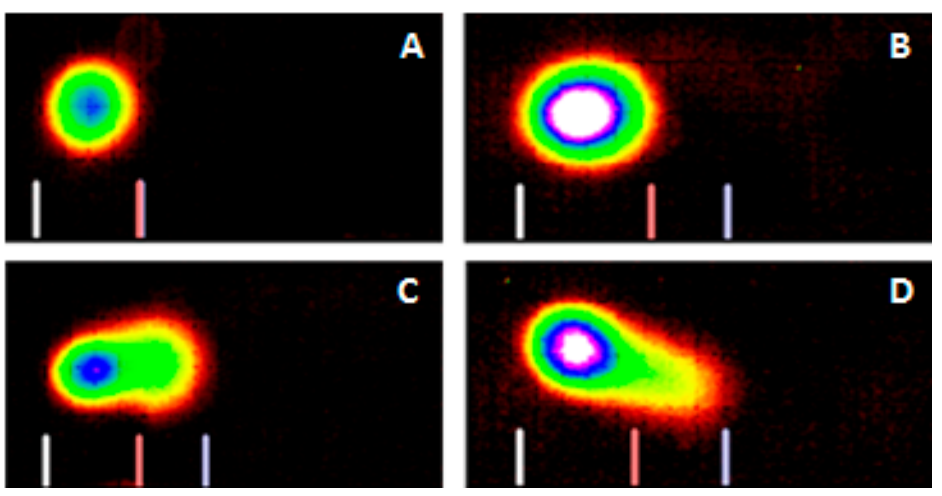

Figure 3. Representative SYBR Green Comet assay images of untreated ((A) - control) and $\mathrm{Pb}\left(\mathrm{NO}_{3}\right)_{2}$ treated HL-60 cells at $10 \mu \mathrm{g} / \mathrm{mL}$ (B); $20 \mu \mathrm{g} / \mathrm{mL}$ (C); and $30 \mu \mathrm{g} / \mathrm{mL}$ (D). High percentages (>45\%) of selected images were observed in specific $\mathrm{Pb}\left(\mathrm{NO}_{3}\right)_{2}$ as indicated above.

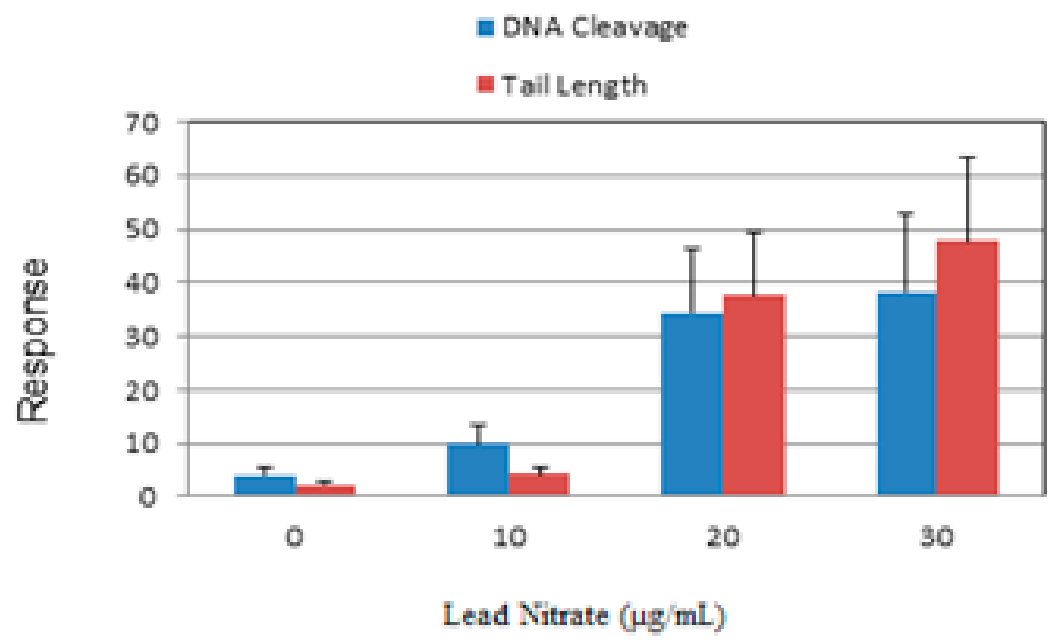

Figure 4. Comet assay of HL-60 cells showing the percentage of DNA cleavage (blue) and tail length (red), as a function of $\mathrm{Pb}\left(\mathrm{NO}_{3}\right)_{2}$ concentrations. Each point represents mean $\pm \mathrm{SD}$ of 3 independent experiments.

\subsection{Lead Nitrate Induced Cell Cycle Arrest}

To further confirm whether the growth inhibition of the cells induced by $\mathrm{Pb}\left(\mathrm{NO}_{3}\right)_{2}$ was related to cell cycle arrest, we analyzed cell cycle profile by flow cytometry assessment. The cell cycle is a highly regulated event that controls the growth and differentiation of cells [38,39]. Changes in cell cycle distribution might be associated with the apoptosis and differentiation of cells. We observed that $\mathrm{Pb}\left(\mathrm{NO}_{3}\right)_{2}$ exposure increased G0/G1 (M1 region) cell population from $42.2 \%$ in the control sample to $70.8 \%$ in treated sample at $30 \mu \mathrm{g} / \mathrm{mL}$ (Figures 5 and 6). Meanwhile the S (M2 region) and $\mathrm{G} 2 / \mathrm{M}$ (M3 and M4 regions) cell populations decreased with increasing concentrations of $\mathrm{Pb}\left(\mathrm{NO}_{3}\right)_{2}$ (Figures 5 and 6). The increase of cell population at the G0/G1 and decrease of cell population at the $\mathrm{S}$ and $\mathrm{G} 2 / \mathrm{M}$ phases suggested that $\mathrm{Pb}\left(\mathrm{NO}_{3}\right)_{2}$ caused cell cycle arrest at the $\mathrm{G} 0 / \mathrm{G} 1$ checkpoint. To the best of our knowledge, no data was found in the literature regarding cell cycle arrest induced by lead in cell lines or animal models. Here, we report for the first time that $\mathrm{Pb}\left(\mathrm{NO}_{3}\right)_{2}$ is able to prominently induce cell cycle arrest at the G0/G1 checkpoint in HL-60 cell lines. In other studies with heavy 
metal toxicity, the antiproliferative action of arsenical compounds was linked to a G1 phase arrest in lymphoid neoplasms [40] and a G2-M phase arrest in NB4 cells [41] at lower doses.
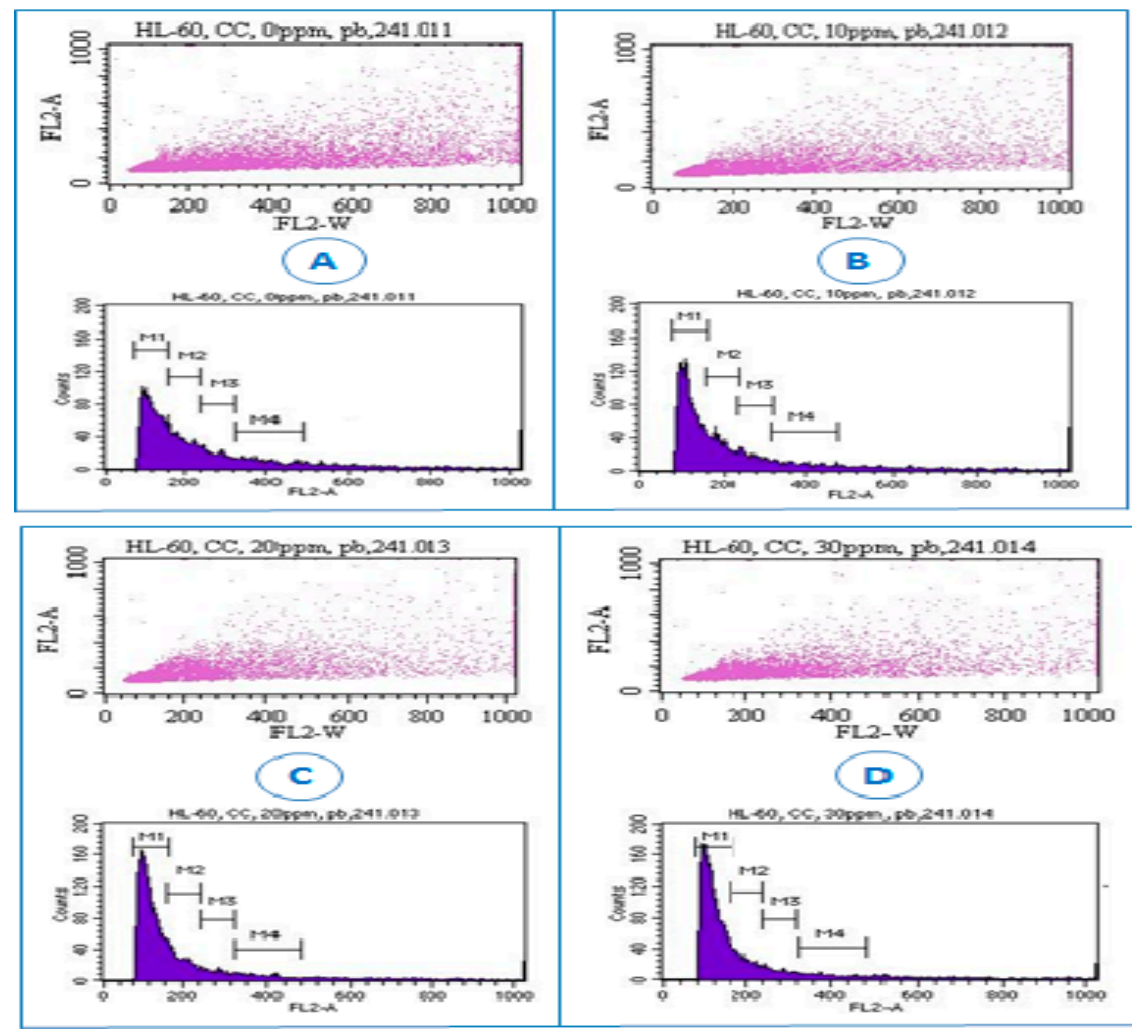

Figure 5. Representative dot plots and histograms showing cell cycle distribution in lead nitrate-treated HL-60 cells. Cell cycle distribution was determined by the propidium iodide staining method, and stained cells were analyzed by flow cytometry (FACS Calibar; Becton-Dickinson) using CellQuest software. A total of 10,000 cells were analyzed per sample. (A) control; (B) $10 \mu \mathrm{g} / \mathrm{mL}$ $\mathrm{Pb}\left(\mathrm{NO}_{3}\right)_{2} ;$ (C) $20 \mu \mathrm{g} / \mathrm{mL} \mathrm{Pb}\left(\mathrm{NO}_{3}\right)_{2} ;$ (D) and $30 \mu \mathrm{g} / \mathrm{mL} \mathrm{Pb}\left(\mathrm{NO}_{3}\right)_{2}$. Three experiments were performed, and 1 representative experiment is shown.

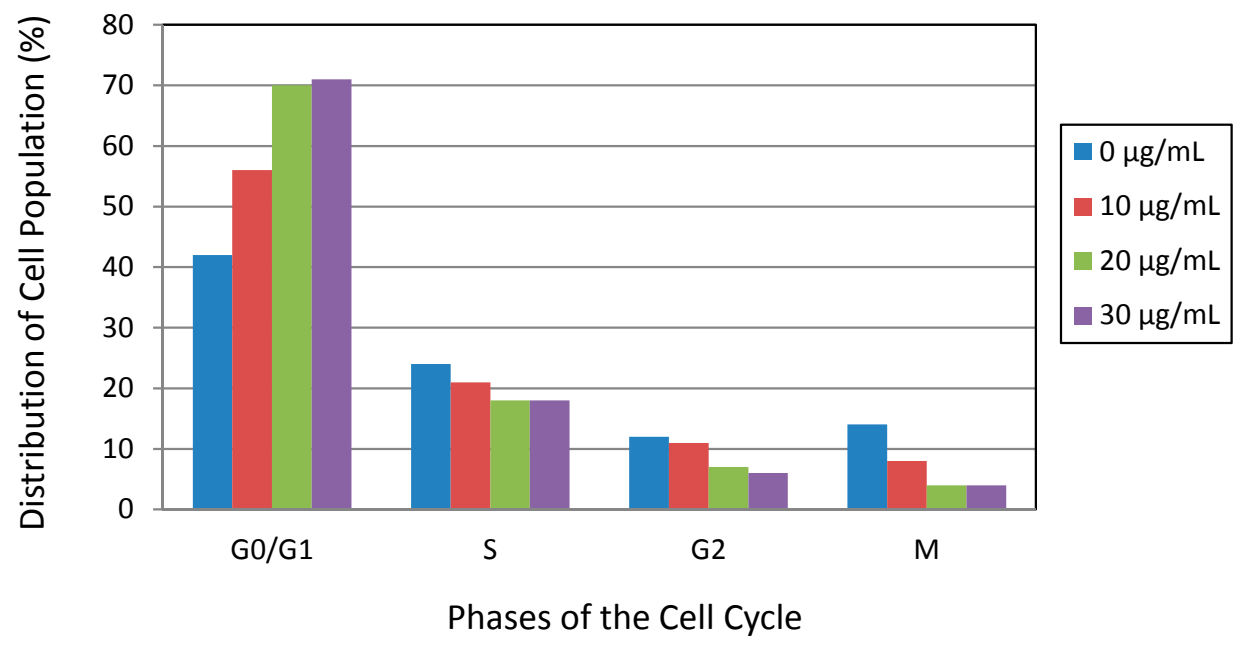

Figure 6. Lead nitrate-induced cell cycle arrest in human leukemia (HL-60) cells. Cells were cultured for $24 \mathrm{~h}$ with different concentrations of $\mathrm{Pb}\left(\mathrm{NO}_{3}\right)_{2}$. Cell cycle distribution was measured by the propidium iodide staining method. Representative results from at least 3 different experiments are shown. 


\subsection{Lead Nitrate Induced Apoptosis}

Despite the fact that lead exposure has been the subject of intense research over many decades, the mechanisms responsible for its apoptotic effects are still poorly understood. A recent study in our laboratory demonstrated that lead exposure induced apoptosis in human leukemia cells at least in part through caspase-3 activation (Figure 7). As seen on Figure 7, the proportion of apoptotic cells (caspase-3 positive cells) increase with increasing concentration of $\mathrm{Pb}\left(\mathrm{NO}_{3}\right)_{2}$ in human leukemia (HL-60) cells. Caspase-3 plays an important role in the downstream of mitochondrial pathway, after dysfunction of mitochondria and the release of cytochrome c. It is well documented that caspase-3 activation occurs in lead induced apoptotic neurodegeneration [42] and apoptosis in HL-60 cells [16]. Caspase-3 is believed to be the final executor of apoptotic DNA damage [43]. In an attempt to further confirm that lead indeed induced apoptosis in human leukemia (HL-60) cells, we performed DNA laddering. Our result showed smear of nucleosomal DNA fragmentation in the nuclei isolated from HL-60 cells (Figure 8). Although we did not detect a direct presence of DNA fragments using the DNA laddering technique, we observed significant DNA damage in the nuclei of HL-60 cells by the comet assay technique (Figure 3). This observation leads us to suggest that nucleosomal DNA fragmentation may be involved in lead-induced apoptosis in human leukemia (HL-60) cells. DNA fragmentation is a biochemical hallmark of apoptosis. Induction of apoptosis has been recognized as a possible outcome of DNA damage for more than 35 years [44]. Studies indicated that apoptosis is associated with lead-induced toxicity in neuronal cells $[45,46]$. Recent report indicated that low-dose exposure to lead and Cadmium significantly cause hepatic and renal apoptosis and impair their function. Hepatic and renal apoptosis induced by low-dose exposure to cadmium and lead was found to be associated with mitochondrial injury and changes in levels of apoptogenic proteins including Bcl-2, Bax, and caspase-3 [47]. Using adult rat hepatic stem cells, Agarwal et al. reported that stimulation of caspase cascade and simultaneous extracellular signal-regulated kinase (ERK) dephosphorylation are the most significant operative pathways directly associated with apoptotic signals triggered by lead acetate [48].
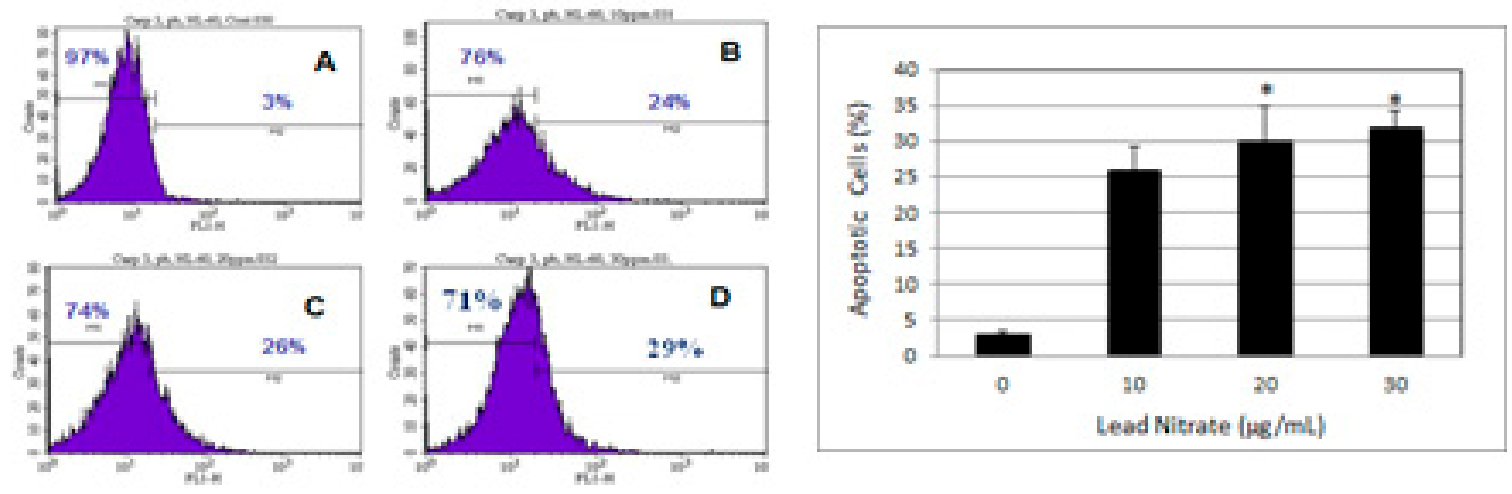

Figure 7. The histogram (Left) shows a comparison of the distribution of negative caspase- 3 cells (M1) and positive caspase-3 cells (M2) after $24 \mathrm{~h}$ incubation in HL-60 cells. A-control; B-10 $\mu \mathrm{g} / \mathrm{mL}$ $\mathrm{Pb}\left(\mathrm{NO}_{3}\right)_{2} ; \mathbf{C}-20 \mu \mathrm{g} / \mathrm{mL} \mathrm{Pb}\left(\mathrm{NO}_{3}\right)_{2} ;$ and $\mathbf{D}-30 \mu \mathrm{g} / \mathrm{mL} \mathrm{Pb}\left(\mathrm{NO}_{3}\right)_{2}$. The bar graph (Right) shows the proportion of apoptotic cells in lead nitrate-treated cells compared to the control. Each point represents the mean value and the standard deviation of three experiments, showing similar results. * Significantly different from control $(0 \mu \mathrm{g} / \mathrm{mL}), p<0.05$ [16]. 


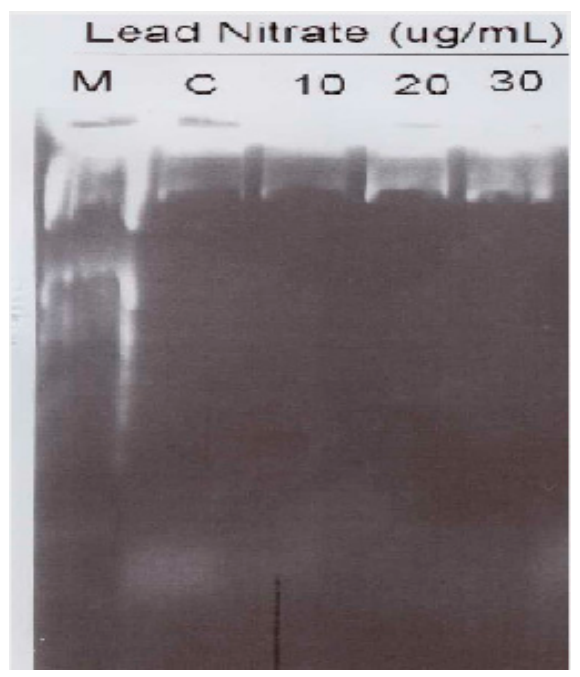

Figure 8. Lead nitrate induced DNA fragmentation in HL-60 cells. DNA marker (M) was electrophoresed as a base pair reference (lane 1). HL-60 cells were either untreated (Lane 2) or treated with 10, 20 and $30 \mu \mathrm{g} / \mathrm{mL}$ of $\mathrm{Pb}\left(\mathrm{NO}_{3}\right)_{2}$ (Lanes 3, 4, and 5) for $24 \mathrm{~h}$. Chromosomal DNA was prepared using the apoptotic DNA ladder detection Kit according to the kit instructions. Twelve microliters of each sample was electrophoresed on a $1.2 \%$ agarose. DNA was stained with ethidium bromide after electrophoresis on a $1.2 \%$ agarose gel and then visualized under UV light.

\section{Conclusions}

In this study, the effect of $\mathrm{Pb}\left(\mathrm{NO}_{3}\right)_{2}$ as one of the hazardous heavy metals was studied at the cellular and molecular levels. From the results obtained in this work, we can conclude that $\mathrm{Pb}\left(\mathrm{NO}_{3}\right)_{2}$ inhibits the cell proliferation of HL-60 cell lines by not only inducing DNA damage and cell cycle arrest at the $G_{0} / G_{1}$ checkpoint but also triggering the apoptosis through caspase-3 activation and nucleosomal DNA fragmentation accompanied by secondary necrosis. As demonstrated in the present study, $\mathrm{Pb}\left(\mathrm{NO}_{3}\right)_{2}$ exposure has a strong cytotoxic, genotoxic, and apoptotic potential effects on human leukemia (HL-60) cells. According to the present finding, its mechanism of action includes growth inhibition of leukemia cells, induction of DNA damage, cell cycle arrest at the $G_{0} / G_{1}$ checkpoint, and apoptosis accompanied by secondary necrotic cell death. Hence, the present study provides a new insight into the mechanisms of $\mathrm{Pb}\left(\mathrm{NO}_{3}\right)_{2}$ induced toxicity and its associated adverse health effects.

Acknowledgments: The research described in this publication was made possible in part by an Institutional Development Award (IDeA) from the National Institute of General Medical Sciences of the National Institutes of Health under grant number P20GM103476 and in part by a grant from the National Institutes of Health (NIMHD-G12MD007581) through the RCMI-Center for Environmental Health at Jackson State University.

Author Contributions: Clement G. Yedjou and Paul B. Tchounwou conceived, designed, and drafted the manuscript; Hervey M. Tchounwou participated in the implementation of the study and acquisition of data. All authors read and approved the final draft of the manuscript.

Conflicts of Interests: The authors declare no conflict of interest.

\section{References}

1. Environmental Protection Agency (EPA). Lead in Drinking Water. 2014. Available online: http://water.epa.gov/drink/info/lead/index.cfm (accessed on 4 January 2014).

2. Brochin, R.; Leone, S.; Phillips, D.; Shepard, N.; Zisa, D.; Angerio, A. The Cellular Effect of Lead Poisioning and Its Clinical Picture. Available online: https://blogs.commons.georgetown.edu/ journal-of-health-sciences / files / Brochin-et-al-2008-GUJHS-5-2-The-Cellular-Effect-of-Lead-Poisoning-andIts-Clinical-Picture.pdf (accessed on 16 August 2015). 
3. Ahmed, Y.F.; Eldebaky, H.A.A.; Mahmoud, K.G.M.; Nawito, M. Effects of lead exposure on DNA damage and apoptosis in reproductive and vital organs in female rabbits. Glob. Vet. 2012, 9, 401-408.

4. Yedjou, C.G.; Haynes, L.; Dorsey, W.; McMurray, R.; Tchounwou, P.B. Lead-induced cytotoxity and oxidative stress in human leukemia (HL-60) cells. Met. Ions Biol. Med. 2008, 10, 489-494.

5. Xu, Y.; Li, G.; Han, C.; Sun, L.; Zhao, R.; Cui, S. Protective effect of Hippophae rhamnoides L. juice on lead-induced neurotoxicity in mice. Biol. Pharm. Bull. 2005, 28, 490-494. [CrossRef] [PubMed]

6. El-Nekeety, A.A.; El-Kady, A.A.; Soliman, M.S.; Hassan, N.S.; Abdel-Wahhab, M.A. Protective effect of Aquilegia vulgaris (L.) against lead acetate-inducedoxidative stress in rats. Food Chem. Toxicol. 2009, 47, 2209-2215. [CrossRef] [PubMed]

7. Wang, M.Z.; Jia, X.Y. Low levels of lead exposure induce oxidative damage and DNA damage in the testes of the frog Rana nigromaculata. Ecotoxicology 2009, 18, 94-99. [CrossRef] [PubMed]

8. Flora, S.J.S.; Pande, M.; Bhadauria, S.; Kannan, G.M. Combined administration of taurine and meso 2,3-dimercaptosuccinic acid in the treatment of chronic lead intoxication in rats. Hum. Exp. Toxicol. 2004, 23, 157-166. [CrossRef] [PubMed]

9. Farmand, F.; Ehdaie, A.; Roberts, C.K.; Sindhu, R.K. Leadinduced dysregulation of superoxide dismutases, catalase, glutathione peroxidase, and guanylate cyclase. Environ. Res. 2005, 98, 33-39. [CrossRef] [PubMed]

10. Bressler, J.; Kim, K.A.; Chakraborti, T.; Goldstein, G. Mechanism of lead neurotoxicity. Neurochem. Res. 1999, 24, 595-600. [CrossRef] [PubMed]

11. ACOG. Committee Opinion Number 533: Lead Screening During Pregnancy and Lactation. 2012. Available online: http://www.acog.org/Resources-And-Publications/Committee-Opinions/Committeeon-Obstetric-Practice/Lead-Screening-During-Pregnancy-and-Lactation (accessed on 16 August 2015).

12. Center for Disease Control and Prevention (CDC). Guidelines for the Identification and Treatment of Lead Exposure in Pregnant and Lactating Women. 2010. Available online: http://www.cdc.gov/nceh/lead/publications/leadandpregnancy2010.pdf (accessed on 16 August 2015).

13. Kwon, S.Y.; Bae, O.N.; Noh, J.Y.; Kim, K.; Kang, S.; Shin, Y.J.; Lim, K.M.; Chung, J.H. Erythrophagocytosis of lead-exposed erythrocytes by renal tubular cells: Possible role in lead-induced nephrotoxicity. Environ. Health Perspect. 2015, 123, 120-127. [CrossRef] [PubMed]

14. Mishra, K.P.; Singh, V.K.; Rani, R.; Yadav, V.S.; Chandran, V.; Srivastava, S.P.; Seth, P.K. Effect of lead exposure on the immune response of some occupationally exposed individuals. Toxicology 2003, 188, 251-259. [CrossRef]

15. Liu, Q.; Chen, R.; Qin, R. Effect of sub-acute low level exposure to lead on cellular immune function in rats. Wei Sheng Yan Jiu 2000, 29, 354-356. [PubMed]

16. Yedjou, C.; Milner, J.; Howard, C.; Tchounwou, P. Basic apoptotic mechanisms of lead toxicity in human leukemia (HL-60) cells. Int. J. Environ. Res. Public Health 2010, 7, 2008-2017. [CrossRef] [PubMed]

17. Yedjou, C.G.; Saeed, M.A.; Hossain, A.; Dorsey, W.; Yu, H.; Tchounwou, P.B. Basic apoptotic and necrotic cell death in human liver carcinoma $\left(\mathrm{HepG}_{2}\right)$ cells induced by synthetic azamacrocycle. Environ. Toxicol. 2014, 29, 605-611. [CrossRef] [PubMed]

18. Collins, A.R. Comet Assay for DNA damage and repair: Principles, applications and limitations. Mol. Biotechnol. 2001, 26, 249-261. [CrossRef]

19. Collins, A.R.; Dusinská, M.; Horská, A. Detection of alkylation damage in human lymphocyte DNA with the comet assay. Acta Biochim. Pol. 2001, 48, 611-614. [PubMed]

20. Yedjou, C.G.; Tchounwou, P.B. In-vitro genotoxic effect of arsenic trioxide to human leukemia (HL-60) cells using the comet assay. Mol. Cell. Biochem. 2007, 301, 123-130. [CrossRef] [PubMed]

21. Yeung, M.C. Accelerated apoptotic DNA laddering protocol. BioTechniques 2002, 33, 734-736. [PubMed]

22. Tchounwou, P.B.; Yedjou, C.G.; Foxx, D.; Ishaque, A.; Shen, E. Lead induced cytotoxicity and transcriptional activation of stress genes in human liver carcinoma cells. Mol. Cell. Biochem. 2004, 255, 161-170. [CrossRef] [PubMed]

23. Tully, D.B.; Collins, B.J.; Overstreet, J.D.; Smith, C.S.; Dinse, G.E.; Mumtaz, M.M.; Chapin, R.E. Effects of arsenic, cadmium, chromium and lead on gene expression regulated by a battery of 13 different promoters in recombinant HepG2 cells. Toxicol. Appl. Pharmacol. 2000, 168, 79-90. [CrossRef] [PubMed]

24. White, L.D.; Cory-Slechta, D.A.; Gilbert, M.E.; Tiffany-Castiglioni, E.; Zawia, N.H.; Virgolini, M.; Rossi-George, A.; Lasley, S.M.; Qian, Y.C.; Basha, M.R. New and evolving concepts in the neurotoxicology of lead. Toxicol. Appl. Pharmacol. 2007, 225, 1-27. [CrossRef] [PubMed] 
25. Centers for Disease Control and Prevention (CDC). Standard Surveillance Definitions and Classifications. 2012. Available online: www.cdc.gov/nceh/lead/data/definitions.htm (accessed on 6 August 2013).

26. Centers for Disease Control and Prevention (CDC). Blood lead levels in young children-United States and selected states, 1996-1999. Morb. Mortal. Wkly. Rep. 2000, 49, 1133-1137.

27. Iavicoli, I.; Marinaccio, A.; Castellino, N.; Carelli, G. Altered cytokine production in mice exposed to lead acetate. Int. J. Immunopathol. Pharmacol. 2004, 17, 97-102. [PubMed]

28. Iavicoli, I.; Carelli, G.; Stanek, E.J.; Castellino, N.; Calabrese, E.J. Below background levels of blood lead impact cytokine levels in male and female mice. Toxicol. Appl. Pharmacol. 2006, 210, 94-99. [CrossRef] [PubMed]

29. Wyllie, A.H. Death from inside out: An overview. Philos. Trans. R. Soc. Lond. B: Biol. Sci. 1994, 345, $237-241$. [CrossRef] [PubMed]

30. Paramjit, G.; Saleha, B.B.; Dana, D.K.; Sayeeda, B. In vivo genotoxic effects of mercuric chloride in rat peripheral blood leucocytes using comet assay. Toxicology 2001, 167, 191-197.

31. Rabbani-Chadegani, A.; Abdosamadi, S.; Fani, N.; Mohammadian, S. A comparison of the effect of lead nitrate on rat liver chromatin, DNA, and histone proteins in solution. Arch. Toxicol. 2010, 83, 565-570. [CrossRef] [PubMed]

32. Pagliara, P.; Carla, E.C.; Caforio, S.; Chionna, A.; Massa, S.; Abbro, L.; Luciana, D. Kupffer cells promote lead nitrate induced hepatocyte apoptosis via oxidative stress. Comp. Hepatol. 2003, 2, 8-21. [CrossRef] [PubMed]

33. Ariza, M.E.; Bijur, G.N.; Williams, M.V. Lead and mercury mutagenesis: Role of $\mathrm{H}_{2} \mathrm{O}_{2}$, superoxide dismutase, and xanthine oxidase. Environ. Mol. Mutagen. 1998, 31, 352-361. [CrossRef]

34. Yang, J.L.; Yeh, S.C.; Chang, C.Y. Lead acetate mutagenicity and mutational spectrum in the hypoxanthine guanine phosphoribosyltransferase gene of Chinese hamster ovary K1 cells. Mol. Carcinog. 1996, 17, 181-191. [CrossRef]

35. Poma, A.; Pittaluga, E.; Tucci, A. Lead acetate genotoxicity on human melanoma cells in vitro. Melanoma Res. 2003, 13, 563-566. [CrossRef] [PubMed]

36. Roy, N.; Rossman, T. Mutagenesis and comutagenesis by lead compounds. Mutat. Res. 1992, 298, 97-103. [CrossRef]

37. Wise, J.P.; Orenstein, J.M.; Patierno, S.R. Inhibition of lead chromate clastogenesis by ascorbate: Relationship to particle dissolution and uptake. Carcinogenesis 1993, 14, 429-434. [CrossRef] [PubMed]

38. Darzynkiewicz, Z.; Zhao, H.; Halicka, H.D.; Rybak, P.; Dobrucki, J.; Wlodkowic, D. DNA damage signaling assessed in individual cells in relation to the cell cycle phase and induction of apoptosis. Crit. Rev. Clin. Lab. Sci. 2011, 49, 199-217. [CrossRef] [PubMed]

39. Jakoby, M.; Schnittger, A. Cell cycle and differentiation. Curr. Opin. Plant Biol. 2004, 7, 661-669. [CrossRef] [PubMed]

40. Zhang, W.; Ohnishi, K.; Shigeno, K.; Fugisawa, S.; Naito, K.; Nakamura, S.; Takeshita, K.; Takeshita, A.; Ohno, R. The induction of apoptosis and cell cycle arrest by arsenic trioxide in lymphoid neoplasms. Leukemia 1998, 12, 1383-1391. [CrossRef] [PubMed]

41. Ma, D.C.; Sun, Y.H.; Chang, K.Z.; Ma, X.F.; Huang, S.L.; Bai, Y.H.; Kang, J.; Liu, Y.G.; Chu, J.J. Selective induction of apoptosis of NB4 cells from G2+M phase by sodium arsenite at lower doses. Eur. J. Haematol. 1998, 61, 27-35. [CrossRef] [PubMed]

42. Xu, J.; Ji, L.D.; Xu, L.H. Lead-induced apoptosis in PC-12 cells: Involvement of p53, Bcl-2 family and caspase-3. Toxicol. Lett. 2006, 166, 160-167. [CrossRef] [PubMed]

43. Naoi, M.; Maruyama, W.; Akao, Y.; Zhang, J.; Parvez, H. Apoptosis induced by an endogenous neurotoxin, $\mathrm{N}$-methyl(R) salsolinol, in dopamine neurons. Toxicology 2000, 153, 123-141. [CrossRef]

44. Wyllie, A.H.; Kerr, J.F.; Currie, A.R. The significance of apoptosis. Int. Rev. Cytol. 1980, 68, $251-306$. [PubMed]

45. Pulido, M.D.; Parrish, A.R. Metal-induced apoptosis: Mechanisms. Mutat. Res. 2003, 533, $227-241$. [CrossRef] [PubMed]

46. Antonio, A.M.; Druse, M.J. Antioxidants prevent ethanol-associated apoptosis in fetal rhombencephalic neurons. Brain Res. 2008, 1204, 16-23. [CrossRef] [PubMed] 
47. Yuan, G.; Dai, S.; Yin, Z.; Lu, H.; Jia, R.; Xu, J.; Song, X.; Li, L.; Shu, Y.; Zhao, X.; et al. Sub-chronic lead and cadmium co-induce apoptosis protein expression in liver and kidney of rats. Int. J. Clin. Exp. Pathol. 2014, 7, 2905-2914. [PubMed]

48. Agarwal, S.; Roy, S.; Ray, A.; Mazumder, S.; Bhattacharya, S. Arsenic trioxide and lead acetate induce apoptosis in adult rat hepatic stem cells. Cell Biol. Toxicol. 2009, 25, 403-413. [CrossRef] [PubMed]

(C) 2015 by the authors; licensee MDPI, Basel, Switzerland. This article is an open access article distributed under the terms and conditions of the Creative Commons by Attribution (CC-BY) license (http://creativecommons.org/licenses/by/4.0/). 